\title{
Effective Biosorption of Nickel(II) from Aqueous Solutions Using Trichoderma viride
}

\author{
P. Sujatha, ${ }^{1}$ V. Kalarani, ${ }^{1}$ and B. Naresh Kumar ${ }^{2}$ \\ ${ }^{1}$ Department of Biotechnology, Sri Padmavati Mahila Visvavidyalayam (Women's University), Andhara Pradesh, \\ Tirupati 517502, India \\ ${ }^{2}$ Food and Water Division, Vimta Life Sciences, Hyderabad 500078, India
}

Correspondence should be addressed to V. Kalarani; kala.dandala@gmail.com

Received 19 February 2012; Revised 27 June 2012; Accepted 7 August 2012

Academic Editor: Veysel T. Yilmaz

Copyright (C) 2013 P. Sujatha et al. This is an open access article distributed under the Creative Commons Attribution License, which permits unrestricted use, distribution, and reproduction in any medium, provided the original work is properly cited.

\begin{abstract}
The primary objective of the present study is to evaluate the optimization conditions such as kinetic and equilibrium isotherm models involved in the removal of $\mathrm{Ni}$ (II) from the aqueous solutions by Trichoderma viride. The biosorbent was characterized by FTIR and SEM. The optimum biosorption conditions were determined as a function of $\mathrm{pH}$, biomass dosage, contact time, initial metal ion concentration, and temperature. The maximum $\mathrm{Ni}(\mathrm{II})$ biosorption was obtained at $\mathrm{pH}$ 4.5. The equilibrium data were better fit by the Langmuir isotherm model than by the Freundlich isotherm. The kinetic studies indicate that the biosorption process of the metal ion $\mathrm{Ni}$ (II) has followed well the pseudo-second-order model. The sum of the square errors (SSE) and chi-square $\left(\chi^{2}\right)$ tests were also carried out to find the best fit kinetic model and adsorption isotherm. The maximum biosorption capacity $\left(q_{m}\right)$ of T. viride biomass was found to be $47.6 \mathrm{mg} / \mathrm{g}$ for $\mathrm{Ni}(\mathrm{II})$ ion. Therefore, it can be concluded that $T$. viride biomass was effective and low-cost potential adsorbent to remove the toxic metal $\mathrm{Ni}$ (II) from aqueous solutions. The recovery process of Ni(II) from $T$. viride biomass was found to be higher than $98 \%$ by using $0.25 \mathrm{M} \mathrm{HNO}_{3}$. Besides the application of removal of toxic metal Ni(II) from aqueous solutions, the biosorbent $T$. viride can be reused for five consecutive sorption-desorption cycles was determined.
\end{abstract}

\section{Introduction}

Metal pollution has been a great concern for the past few decades. It is believed that the wide use of man-made chemicals, anthropogenic lifestyle, and rapid industrialization is the major source of metal toxicity [1]. Nickel is well known as a heavy metal pollutant, present in effluents of electroplating industries, smelting, and alloy manufacturing, mining, and refining industries [2]. According to $\mathrm{WHO}$, the permissible limit of $\mathrm{Ni}(\mathrm{II})$ in drinking water is $0.5 \mathrm{mg} / \mathrm{L}$ [3]. The non-biodegradable and bioaccumulating properties of heavy metals may pose serious threats to living organisms, [4]. It has been reported that both occupational and environmental exposure to trace metals affects almost all compartments of animal systems including human health [1]. In humans and animals, nickel is an essential micronutrient [5] because of its importance in the metabolic pathways. Nickel is one of the cofactors for urease enzyme in plants [6]. Though, it is an essential micronutrient and/or cofactor, nickel is one of the heavy metal toxicants at higher concentration and is a well-known human carcinogen [7]. Nickel has been implicated as an embryotoxin and teratogen [8]. The higher concentration of Nickel causes dermatitis, nausea, vomiting, behavioral, and respiratory problems in addition to cyanosis, gastrointestinal distress, and weakness [9]. All these biological disorder consequences alarm the need of nickel removal from the environment and to bring up its levels below the threshold limits from its sources. The classical physicochemical methods are commonly used for the removal of nickel from the industrial effluents, namely, evaporative recovery, filtration, ion exchange, and membrane technologies. Though they are promising to some extent, but these processes have high reagent or energy requirements and generate toxic sludge that requires careful disposal [10]. Furthermore, insufficient removal of traces of heavy metal ions, varying performances, and also high operating costs has limited the use of conventional physicochemical methods. Thus, there is a need for alternative methods for better efficacy 
with low cost and complete removal of toxic metals from the water bodies.

In recent years, the exploitation of eco-friendly biosorption technology using inactive and dead biomasses to detoxify metal-contaminated effluents in the aquatic environment is gaining importance day by day $[11,12]$. Moreover, the biosorbents have high specific metal binding ability in complex media in contrast to carbonaceous sorbents which tend to adsorb metal ions in a nonspecific manner. These advantages make biosorbents an economical alternative to commercial activated carbons in the removal of heavy metalpolluted water bodies [13].

The application of fungal organisms in the field of biosorption technology has become a part of active research by the environmental scientists. Fungal organisms like, Aspergillus niger [14], Streptomyces noursei [15], Pseudomonas aeruginosa [16], and Rhizopus arrhizus [17] have been reported for removal of heavy metals, such as $\mathrm{Pb}$, $\mathrm{Cd}$, and, in particular, $\mathrm{Ni}(\mathrm{II})$. Among the fungal organisms, the T. viride in biosorption process is little exploited [18]. The present study in our laboratory is mainly aimed at knowing the application of $T$. viride for sequestration of $\mathrm{Ni}$ (II) from contaminated water systems involving kinetic and equilibrium. The selection of this biosorbent $T$. viride is based on (1) inexpensive, (2) easily available, (3) no toxic effects of its own, and (4) some information suggests that metal-bioaccumulation properties of T. viride [19]. Hence, studies on the kinetic and equilibrium isotherm models have been studied, in order to systematically investigate the application of biomass, T. viride as biosorbent for the removal of nickel ions from water/industrial waste water. The optimum conditions for biosorption such as $\mathrm{pH}$, initial metal ion concentration, biomass dosage, contact time, and equilibrium isotherm models in relation to the biosorption of $\mathrm{Ni}(\mathrm{II})$ onto T. viride have been investigated. In addition to this, the $\mathrm{Ni}(\mathrm{II})$ ion desorption studies have been performed over five sorption-desorption cycles to evaluate the sorbent T. viride for reusage.

\section{Experimental}

2.1. Collection and Preparation of Biomass (Adsorbent). The fungal biomass was collected from Microbial Type Culture Collection (MTCC), Chandigarh, India. The biomass was prepared in the sabouraud broth (peptone 10.0, dextrose 40.0 , streptomycin 0.03 , and agar $20.0 \mathrm{~g} / \mathrm{L}$ ) by inoculating the $0.1 \mathrm{~mL}$ spore suspension $/ 100 \mathrm{~mL}$ of water in the $250 \mathrm{~mL}$ flasks and incubated at room temperature for 5-7 days. Samples were washed several times using deionized water to remove adhesive materials such as extraneous salts and then dried in oven at $60^{\circ} \mathrm{C}$ for $48 \mathrm{~h}$ and powdered to uniform size using a mortar.

2.2. Reagents and Equipments. A flame atomic absorption spectrophotometer (Shimadzu AA-6300, Japan) with nickel hallow cathode lamp was used for determination of $\mathrm{Ni}(\mathrm{II})$ before and after biosorption. Absorbance was measured at wavelength of $232 \mathrm{~nm}$ and spectral bandwidth was $0.2 \mathrm{~nm}$.

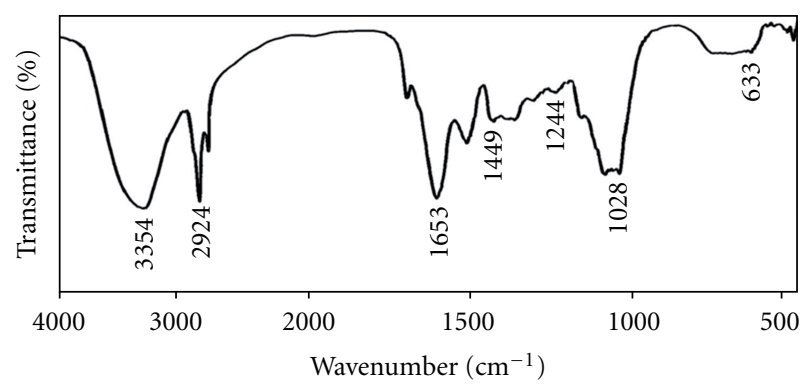

(a) Unloaded

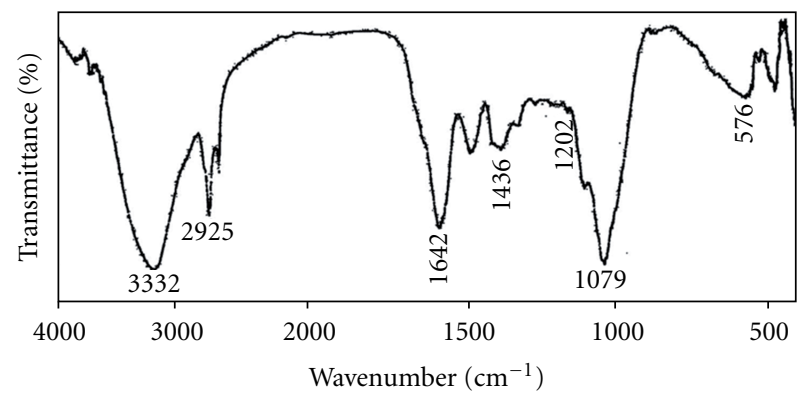

(b) Total nickel loaded

FIGURE 1: FTIR spectra of T. viride biomass before adsorption (a) and after adsorption of Nickel (b).

Fourier Transform Infrared (FT-IR) spectrometer (ThermoNicolet FT-IR, Nicolet IR-200, USA) was used for IR spectral studies of dried biomass and $\mathrm{Ni}(\mathrm{II})$-sorbed biomass in the range of $4000-400 \mathrm{~cm}^{-1}$ and Scanning Electron Microscopy (SEM, Model Evo15, Carl Zeiss, England) has been used to study the surface morphology of the biosorbent.

\section{Results and Discussion}

3.1. Characterization of Biomass. The FTIR spectra of free biomass and nickel sorbed biomass samples were showed in Figure 1. The spectra of free biomass (Figure 1(a)) has shown a broad and strong peak at $3354 \mathrm{~cm}^{-1}$, which may be due to the overlapping of $\mathrm{O}-\mathrm{H}$ and $\mathrm{N}-\mathrm{H}$ stretching vibrations. The peak at $2924 \mathrm{~cm}^{-1}$ can be assigned to the $-\mathrm{CH}$ groups of an unloaded biomass sample. The peaks at 1642 and $1653 \mathrm{~cm}^{-1}$ may be attributed to asymmetric and symmetric stretching vibration of $\mathrm{C}=\mathrm{O}$ groups, respectively. The spectrum of nickel sorbed biomass (Figure 1(b)) has revealed that the bands that have been observed at 3332,1436 , 1202 , and $1079 \mathrm{~cm}^{-1}$ for free biomass are shifted to 3354 , 1449,1244 , and $1028 \mathrm{~cm}^{-1}$. The significant changes in the wave numbers of these specific peaks have suggested that amine, hydroxyl, $\mathrm{C}=\mathrm{O}$, and alcoholic $\mathrm{C}-\mathrm{O}$ groups of biomass could be involved in the biosorption of nickel ion onto $T$. viride.

Figure 2 shows the morphology of T. viride before and after biosorption of $\mathrm{Ni}(\mathrm{II})$. Before $\mathrm{Ni}$ (II) biosorption on $\mathrm{T}$. viride shows adhesive and small particles (Figure 2(a)). It has been shown that the morphology changed to a corn flakelike structure after $\mathrm{Ni}$ (II) biosorption onto T. viride biomass 


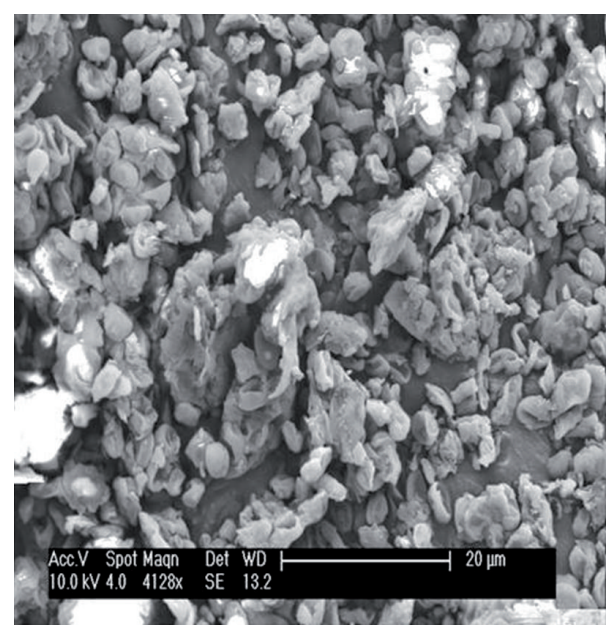

(a)

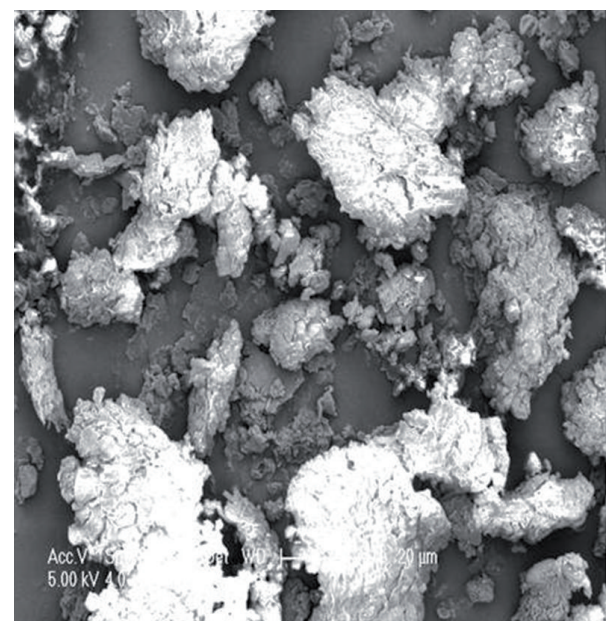

(b)

FIGURE 2: SEM micrographs of T. viride biomass surface, (a) before adsorption of $\mathrm{Ni}$ (II) ions and (b) after adsorption of $\mathrm{Ni}$ (II) ions.

(Figure 2(b)). It can be seen that the surface modifications occurred by reducing the irregularity, after binding of $\mathrm{Ni}$ (II) ions onto the surface $T$. viride biomass.

3.2. Effect of $P H$. Biosorption of $\mathrm{Ni}(\mathrm{II})$ onto biomass of $T$. viride as a function of initial $\mathrm{pH}$ has been shown in Figure 3. It has been observed that the biosorption capacity is increased from $\mathrm{pH} 2.0$ to 4.5. Beyond $\mathrm{pH} 4.5$, the biosorption has gradually decreased. At lower $\mathrm{pH}$, the cell wall of $T$. viride becomes positively charged due to the increase in hydrogen ion concentration which is responsible for reduction in biosorption of $\mathrm{Ni}$ (II) ions on adsorption sites. In contrast, at higher $\mathrm{pH}(>4.5)$, the cell wall surface becomes more negatively charged when compared to surface negative charges at lower $\mathrm{pH}$. At $\mathrm{pH}$ greater than 4.5, nickel ions start binding with $\mathrm{OH}^{-}$forming the insoluble nickel hydroxides that resulted in the reduction of biosorption.

3.3. Effect of Biosorbent Dose on Biosorption. The biosorbent dosage is an important parameter which determines the

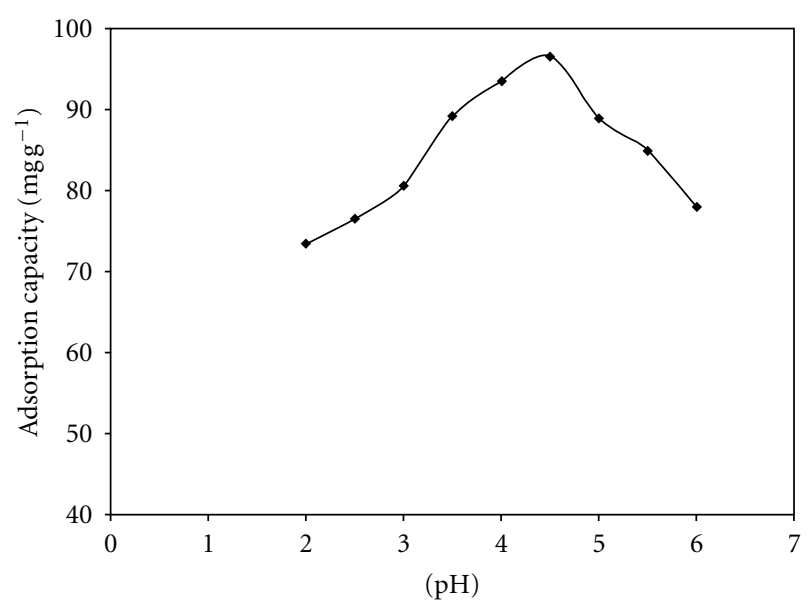

FIgURE 3: Effect of $\mathrm{pH}$ on the biosorption of $\mathrm{Ni}(\mathrm{II})$ onto T. viride biomass.

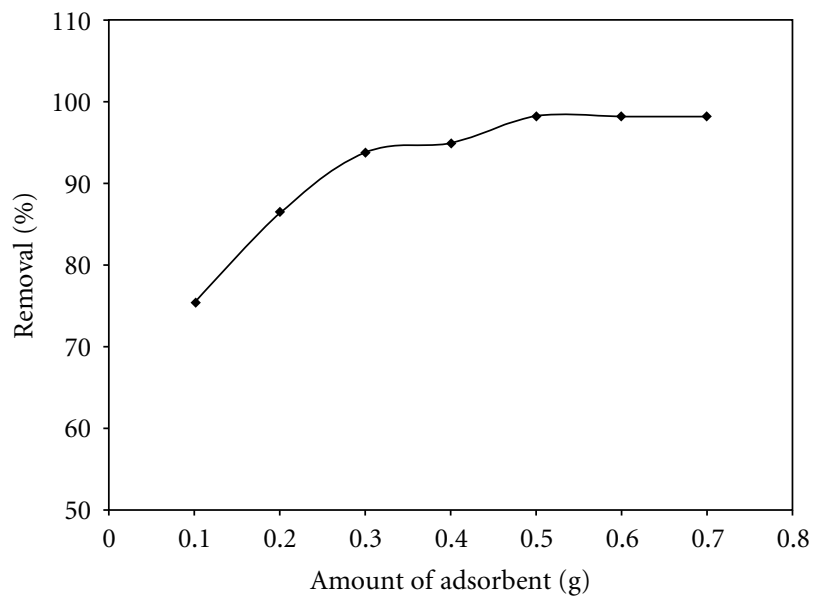

FIgURE 4: Effect of biosorbent dosage level on the biosorption of $\mathrm{Ni}(\mathrm{II}) \mathrm{T}$. viride biomass.

capacity of a biosorbent for a given initial concentration. The biosorption of $\mathrm{Ni}$ (II) ion as a function of the biosorbent dosage of $0.1 \mathrm{~g}$ to $0.7 \mathrm{~g}$ has been investigated and the results are shown in Figure 4 . The percentage of biosorption has increased with the increase of biosorbent dose up to $0.5 \mathrm{~g} / 0.1 \mathrm{~L}$. At the initial concentration of $100 \mathrm{mg} / \mathrm{L}$ of $\mathrm{Ni}(\mathrm{II})$, the maximum percentage removal was $92.3 \%$ and remained constant at $>0.5 \mathrm{~g} / 0.1 \mathrm{~L}$. Therefore, the optimum biosorbent dosage was taken as $0.5 \mathrm{~g}$ for further experiments to determine the effect of contact time, biosorption kinetics, and biosorption isotherm models.

3.4. Effect of Contact Time. The biosorption capacity of T. viride towards $\mathrm{Ni}$ (II) was investigated at different initial concentrations and fixed amount of fungi at different time intervals. The efficacy of biosorption increases with agitation time and reached equilibrium about $180 \mathrm{~min}$ for all the experimental concentrations performed. The rate of the uptake of metal ions was rapid in the early stages as expected, then the equilibrium was attained due to continuous formation of the 
TABLE 1: Kinetic parameters for biosorption of Ni(II) by T. viride biomass.

\begin{tabular}{cccccccccc}
\hline \multirow{2}{*}{ Metal ion } & \multicolumn{3}{c}{ Lagergren first order } & \multicolumn{3}{c}{ Pseudo second order } & \multicolumn{3}{c}{ Weber and Morris } \\
& $K_{1}\left(\mathrm{~min}^{-1}\right)$ & $R^{2}$ & $\mathrm{SSE}$ & $K_{2}(\mathrm{~g} /(\mathrm{mg} \mathrm{min}))$ & $R^{2}$ & $\mathrm{SSE}$ & $K_{\text {id }}\left(\mathrm{mg} / \mathrm{g} \mathrm{min}{ }^{-0.5}\right)$ & $R^{2}$ & $\mathrm{SSE}$ \\
\hline \multirow{3}{*}{$\mathrm{Ni}(\mathrm{II})$} & 0.0165 & 0.9982 & 0.995 & 0.0004 & 0.999 & 0.011 & 2.328 & 0.9498 & 0.922 \\
& 0.0158 & 0.9856 & 0.998 & 0.0004 & 0.997 & 0.003 & 2.934 & 0.9877 & 0.943 \\
& 0.0127 & 0.9921 & 0.999 & 0.0004 & 0.997 & 0.004 & 3.809 & 0.9869 & 0.951 \\
& 0.0134 & 0.9968 & 0.999 & 0.0004 & 0.999 & 0.003 & 4.559 & 0.9713 & 0.934 \\
\hline
\end{tabular}

biosorption layer until saturation. The data obtained from the experiment has been further used to evaluate the kinetic parameters of the biosorption process.

3.5. Biosorption Kinetics. The mechanism of biosorption depends on the physical and chemical characteristics of the adsorbents as well as on the mass transfer process [20]. The results of rate kinetics of $\mathrm{Ni}(\mathrm{II})$ biosorption onto $T$. viride biomass are analyzed using pseudo-first-order, pseudosecond-order, and intraparticle diffusion models. The conformity between experimental data and the model predicted values was expressed by correlation coefficients $\left(R^{2}\right)$.

The linear pseudo-first-order model [21] can be represented by the following equation:

$$
\log \left(q_{e}-q_{t}\right)=\log q_{e}-\frac{k_{1} t}{2.303}
$$

where $q_{e}(\mathrm{mg} / \mathrm{g})$ and $q_{t}(\mathrm{mg} / \mathrm{g})$ are the amounts of adsorbed metal on the sorbent at the equilibrium time and at any time $t$, respectively, and $k_{1}$ is the rate constant of pseudo-firstorder adsorption process $\left(\mathrm{min}^{-1}\right)$. The experimental data was fitted to (1) and various parameters obtained for biosorption of $\mathrm{Ni}(\mathrm{II})$ onto $T$. viride with different initial concentrations together with correlation coefficients are given in Table 1 . The correlation coefficients for the pseudo-first-order equation obtained at all the studied concentrations were low. This suggests that this biosorption system does not follow the firstorder reaction.

The kinetics of biosorption process may also be described by pseudo-second-order rate equation [22]. The lineralized form of equation was given as follows:

$$
\frac{t}{q_{t}}=\frac{1}{k_{2} q_{e}^{2}}+\frac{1}{q_{e}} t,
$$

where $k_{2}(\mathrm{~g} /(\mathrm{mg} \mathrm{min}))$ is the equilibrium rate constant of pseudo-second-order biosorption. The pseudo-second-order equation parameters obtained for biosorption of $\mathrm{Ni}$ (II) onto T. viride with different initial concentrations together with correlation coefficients are given in Table 1.

The biosorption results were analyzed using intraparticle diffusion model [23]. This is represented as

$$
q_{t}=k_{\mathrm{id}} t^{0.5}+c
$$

where $q_{t}(\mathrm{mg} / \mathrm{L})$ is the amount adsorbed at time $t$ (min) and $k_{\mathrm{id}}\left(\mathrm{mg} / \mathrm{g} \mathrm{min}{ }^{-0.5}\right)$ is the rate constant of intraparticle diffusion. $C$ is the value of intercept which gives an idea about the boundary layer thickness, that is, the larger intercept,

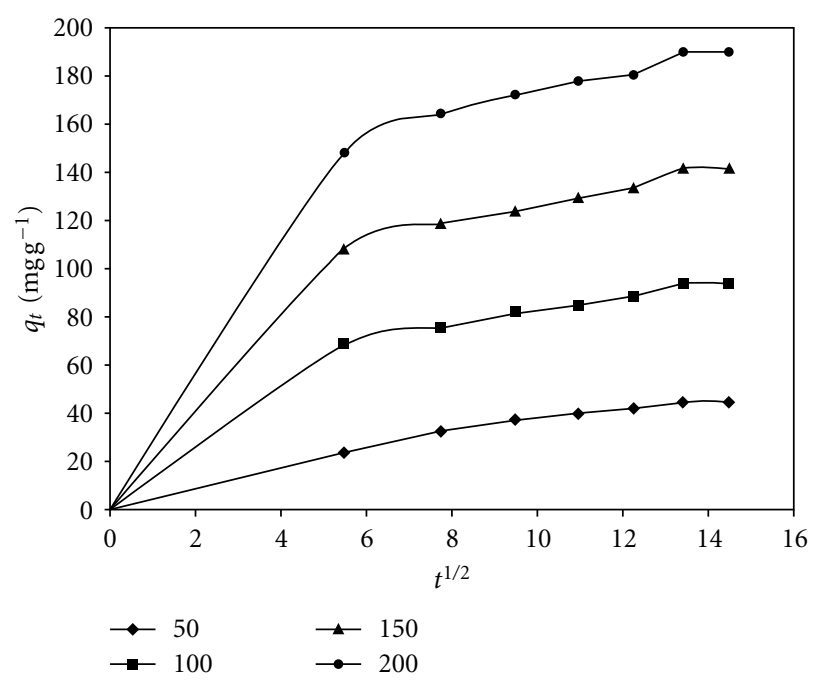

Figure 5: Weber and Morris plots for the biosorption of Ni(II) $T$. viride biomass.

the greater is the boundary effect. The Weber Morris plot for biosorption of $\mathrm{Ni}$ (II) is given in Figure 5. Based on the results, it can be concluded that both film diffusion and intraparticle diffusion are simultaneously operating during the biosorption of $\mathrm{Ni}(\mathrm{II})$ onto $T$. viride biomass.

3.6. Fitness of the Biosorption Kinetic Models. The values of rate constants and correlation coefficients for each model were shown in Table 1 . The best fit among the kinetic models is assessed by the squared sum of error (SSE) values. It is assumed that the model which gives the lower SSE values is the best model for metal ion sorption on T. viride. The SSE values are calculated by the following equation:

$$
\mathrm{SSE}=\sum\left(\frac{\left(q_{t, e}-q_{t, m}\right)^{2}}{q^{2}}\right)
$$

where $q_{t, e}$ and $q_{t, m}$ are the experimental biosorption capacities of metal ions $(\mathrm{mg} / \mathrm{g})$ at time $\mathrm{t}$ and the corresponding values that are obtained from the kinetic models. SSE values for all the kinetic models are calculated and summarized in Table 1. The lower SSE values of pseudo-second-order model indicate that the biosorption of $\mathrm{Ni}(\mathrm{II})$ on the $T$. viride biosorbent follows the pseudo-second-order kinetic model.

3.7. Biosorption Isotherms Models. The equilibrium adsorption isotherm is of importance in the design of adsorption 
systems [24]. The adsorption isotherms for $\mathrm{Ni}(\mathrm{II})$ adsorption onto $T$. viride biomass at the temperature of 20,30 , and $40^{\circ} \mathrm{C}$ are shown in Figures 6(a) and 6(b). The Langmuir treatment is based on the assumption that the maximum adsorption corresponds to a saturated monolayer of solute molecules on the adsorbent surface, that the energy of adsorption is constant, and there is no transmigration of adsorbate in the plane of the surface [25]. It is represented by

$$
q_{e}=\frac{q_{m} K_{L} C_{e}}{1+K_{L} C_{e}}
$$

where $q_{e}$ is the equilibrium metal ion concentration on the sorbent ( $\mathrm{mg} / \mathrm{g}), C_{e}$ is the equilibrium metal ion concentration in the solution $(\mathrm{mg} / \mathrm{L}), q_{m}$ is the monolayer sorption capacity of the sorbent $(\mathrm{mg} / \mathrm{g})$, and $K_{L}$ is the Langmuir sorption constant $(\mathrm{L} / \mathrm{mg})$ related to the free energy of sorption. Figure 6(a) shows the Langmuir plots at different temperatures and the constants $q_{m}$ and $K_{L}$ are tabulated in Table 2. On the other hand, Table 3 presents the comparison of biosorption capacity (mg/g) of T. viride for $\mathrm{Ni}(\mathrm{II})$ ions with that of various biosorbents reported in the literature [26-28].

The general form of Freundlich is given as follows:

$$
q_{e}=k_{f} C_{e}^{1 / n}
$$

where $K_{f}$ is a constant related to the biosorption capacity and $1 / n$ is an empirical parameter related to the biosorption intensity, which varies with the heterogeneity of the material. Figure 6(b) shows the Freundlich plots at different temperatures and the constant $K_{f}$ and $1 / n$ are tabulated in Table 2. The best fit biosorption isotherm model is confirmed by the correlation coefficients $\left(R^{2}\right)$ and the chi-square $\left(\chi^{2}\right)$ tests. The equation for evaluating the best fit model is to be written as

$$
\chi^{2}=\sum\left(\frac{\left(q_{e}-q_{e, m}\right)^{2}}{q_{e, m}}\right),
$$

where $q_{e}$ is the experimental data of the equilibrium capacity $(\mathrm{mg} / \mathrm{g})$ and $q_{e, m}$ is equilibrium capacity obtained by calculating from the model $(\mathrm{mg} / \mathrm{g}) \cdot \chi^{2}$ will be a small number if the data from the model are similar to the experimental data, while $\chi^{2}$ will be a bigger number if they differ. Thus, it is also necessary to analyse the data set using the nonlinear $\chi^{2}$ test to confirm the best-fit isotherm for the biosorption process and the $\chi^{2}$ values are given in Table 2 . The $\chi^{2}$ values of both isotherms are comparable and hence the adsorption of metal ions follows both Freundlich and Langmuir isotherms and better fit to Langmuir as its $\chi^{2}$ value is less than that of the Freundlich model.

3.8. Desorption Experiment. In addition to biosorption studies, desorption processes have equal importance due to the reusage of biomass material. Desorption mainly depends upon (a) type of eluents and (b) biomass material used. In the present study, $\mathrm{HNO}_{3}$ solution was used as the eluent to remove $\mathrm{Ni}(\mathrm{II})$ from $\mathrm{T}$. viride. Different concentrations

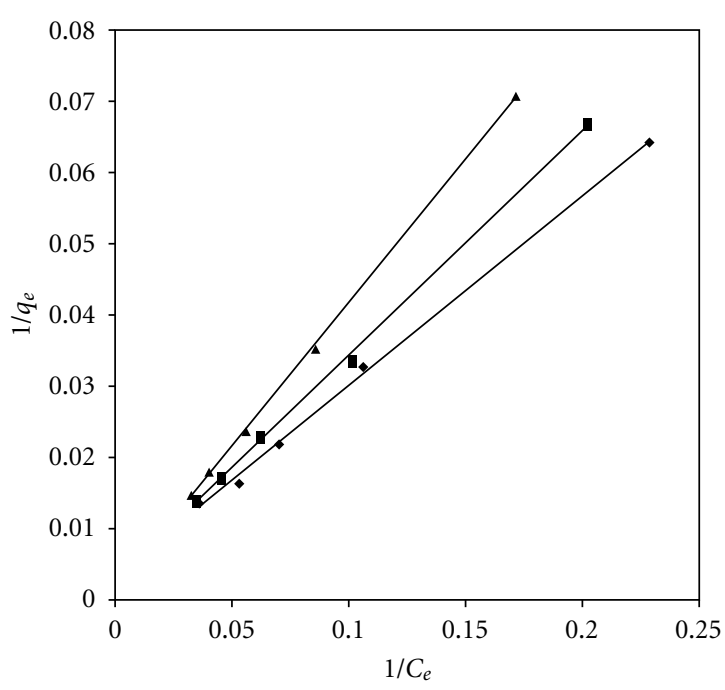

(a)

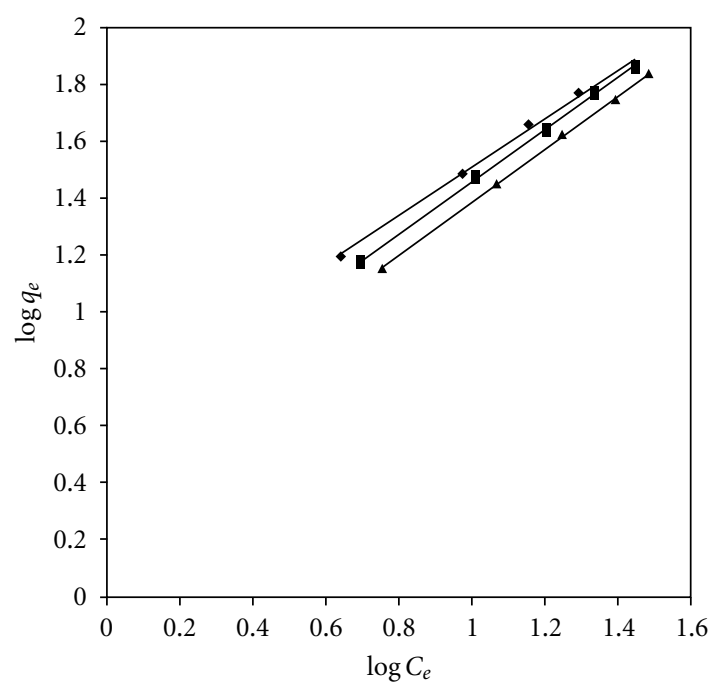

(b)

FIGURE 6: (a) Langmuir isotherm plots for the biosorption of $\mathrm{Ni}(\mathrm{II})$ T. viride biomass at different temperatures. (b) Freundlich isotherm plots for the biosorption of $\mathrm{Ni}(\mathrm{II}) \mathrm{T}$. viride biomass at different temperatures.

(0.01-0.4 M) were used to desorb the $\mathrm{Ni}(\mathrm{II})-T$. viride complex. The results of the present study indicate that the addition of acid at lower concentration $0.01 \mathrm{M} \mathrm{HNO}_{3}$ desorbs the nickel from the complex and $>55 \%$ adsorption was observed at $0.05 \mathrm{M} \mathrm{HNO}_{3}$. The maximum desorption (>98\%) of nickel from the complex occurs at $>0.25 \mathrm{M} \mathrm{HNO}_{3}$.

3.9. Recovery of Ni(II) by Adsorption-Desorption Cycle. In order to evaluate the reutilization of the $T$. viride, the biosorption-desorption cycles are repeated five times by treating the used biosorbent with $0.25 \mathrm{M} \mathrm{HNO}_{3}$. The desorption efficiency of $99.77 \%$ of $\mathrm{Ni}$ (II) was obtained by using $0.25 \mathrm{M} \mathrm{HNO}_{3}$ in the first cycle and is, therefore, suitable for regeneration of biosorbent. There was a gradual decrease of 
TABLE 2: Langmuir and Freundlich isotherm parameters for the biosorption of Ni(II) on T.viride biomass at different temperatures.

\begin{tabular}{cccccccccc}
\hline \multirow{2}{*}{ Metal ion } & \multirow{2}{*}{ Temperatures $(K)$} & \multicolumn{3}{c}{ Langmuir } & \multicolumn{3}{c}{ Freundlich } \\
& & $q_{\max }(\mathrm{mg} / \mathrm{g})$ & $K_{L}(\mathrm{~L} / \mathrm{mg})$ & $R^{2}$ & $\chi^{2}$ & $K_{f}(\mathrm{mg} / \mathrm{g})$ & $n$ & $R^{2}$ \\
\hline \multirow{3}{*}{$\mathrm{Ni}(\mathrm{II})$} & 293 & 26.3 & 2.57 & 0.999 & 11.25 & 4.538 & 1.174 & 0.993 \\
& 303 & 37.0 & 3.15 & 0.999 & 17.28 & 3.566 & 1.1047 & 0.999 & 62.1 \\
& 313 & 47.6 & 3.68 & 0.999 & 21.67 & 2.875 & 1.076 & 0.999 & 69.9 \\
\hline
\end{tabular}

TABLE 3: A comparison of biosorption capacity ( $\mathrm{mg} / \mathrm{g})$ of different biomasses for $\mathrm{Ni}(\mathrm{II})$ removal.

\begin{tabular}{lcc}
\hline Biomass & $q_{m}(\mathrm{mg} / \mathrm{g})$ & References \\
\hline Rhizopus nigricans & 5 & {$[26]$} \\
Streptomyces noursei & 0.8 & {$[26]$} \\
Waste pomace of olive factory & 14.80 & {$[27]$} \\
PAC (Powdered activated carbon) & 31.08 & {$[28]$} \\
T. viride & 47.6 & (Present study) \\
\hline
\end{tabular}

$\mathrm{Ni}(\mathrm{II})$ biosorption on $T$. viride with an increase the number of desorption cycles. After a sequence of five cycles, it was observed that the $\mathrm{Ni}$ (II) uptake capacity of the $T$. viride has been reduced from $98.15 \%$ to $95.13 \%$. The desorption efficiency more than $98 \%$ recovery of $\mathrm{Ni}(\mathrm{II})$ was observed in each cycle of all the five consecutive desorption cycles. The results indicate that the $T$. viride can be used repeatedly in the adsorption-desorption cycles.

\section{Conclusion}

This study is focused on the biosorption of $\mathrm{Ni}$ (II) ion onto T. viride biomass from aqueous solution. The operating parameters, $\mathrm{pH}$ of solution, biomass dosage, contact time, initial metal ion concentration, and temperature are effective on the biosorption efficiency of $\mathrm{Ni}(\mathrm{II})$. The biosorption capacity of $T$. viride biomass has been found to be $47.6 \mathrm{mg} / \mathrm{g}$ for $\mathrm{Ni}(\mathrm{II})$. Langmuir model has fitted the equilibrium data better than the Freundlich isotherm. The kinetic data has illustrated that pseudo-second-order model is more suitable than a pseudo-first-order model based on the lower SSE and correlation coefficients that are greater than 0.99. T. viride can be used for 5 cycles by regenerating with $0.25 \mathrm{M} \mathrm{HNO}_{3}$. Further, it can be evaluated as an alternative biosorbent to treat wastewater containing $\mathrm{Ni}$ (II) ion over the classical physicochemical methods. Hence, T. viride can be used as an effective, low-cost biosorbent for potential removal of heavy toxic metal $\mathrm{Ni}$ (II) from aqueous media. The significant advantage of T. viride is reusage of it when compared to other methods using different types of fungi for removal of $\mathrm{Ni}(\mathrm{II})$ from water media.

\section{References}

[1] J. Wang and C. Chen, "Biosorbents for heavy metals removal and their future," Biotechnology Advances, vol. 27, no. 2, pp. 195-226, 2009.
[2] E. Denkhaus and K. Salnikow, "Nickel essentiality, toxicity, and carcinogenicity," Critical Reviews in Oncology/Hematology, vol. 42, no. 1, pp. 35-56, 2002.

[3] World Health Organization, Guidelines for Drinking-Water Quality, Incorporating First addendum to Third Edition, vol. 1, World Health Organization, Geneva, Switzerland, 3rd edition, 2006.

[4] Y. Liu and H. Xu, "Equilibrium, thermodynamics and mechanisms of $\mathrm{Ni}^{2+}$ biosorption by aerobic granules," Biochemical Engineering Journal, vol. 35, no. 2, pp. 174-182, 2007.

[5] E. O. Uthus and C. D. Seaborn, "Deliberations and evaluations of the approaches, endpoints and paradigms for dietary recommendations of the other trace elements," Journal of Nutrition, vol. 126, no. 9, supplement, pp. 2452S-2459S, 1996.

[6] R. K. Watt and P. W. Ludden, "Nickel-binding proteins," Cellular and Molecular Life Sciences, vol. 56, no. 7-8, pp. 604-625, 1999.

[7] M. G. Maleva, G. F. Nekrasova, P. Malec, M. N. V. Prasad, and K. Strzałka, "Ecophysiological tolerance of Elodea canadensis to nickel exposure," Chemosphere, vol. 77, no. 3, pp. 392-398, 2009.

[8] C.-Y. Chen and T.-H. Lin, "Nickel toxicity to human term placenta: in vitro study on lipid peroxidation," Journal of Toxicology and Environmental Health A, vol. 54, no. 1, pp. 37-47, 1998.

[9] N. Akhtar, J. Iqbal, and M. Iqbal, "Removal and recovery of nickel(II) from aqueous solution by loofa sponge-immobilized biomass of Chlorella sorokiniana: characterization studies," Journal of Hazardous Materials, vol. 108, no. 1-2, pp. 85-94, 2004.

[10] J. Wild, "Liquid wastes from the metal finishing industry," in Surveys in Industrial Waste Water Treatment, D. Barnes, C. F. Forster, and S. E. Hrudey, Eds., pp. 21-62, John Wiley and Sons, New York, NY, USA, 1987.

[11] G. H. Pino, L. M. S. De Mesquita, M. L. Torem, and G. A. S. Pinto, "Biosorption of heavy metals by powder of green coconut shell," Separation Science and Technology, vol. 41, no. 14, pp. 3141-3153, 2006.

[12] G. H. Pino, L. M. Souza De Mesquita, M. L. Torem, and G. A. S. Pinto, "Biosorption of cadmium by green coconut shell powder," Minerals Engineering, vol. 19, no. 5, pp. 380-387, 2006.

[13] V. K. Gupta and A. Rastogi, "Biosorption of lead(II) from aqueous solutions by non-living algal biomass Oedogonium sp. and Nostoc sp.: a comparative study," Colloids and Surfaces B, vol. 64, no. 2, pp. 170-178, 2008.

[14] A. Kapoor, T. Viraraghavan, and D. R. Cullimore, "Removal of heavy metals using the fungus Aspergillus niger," Bioresource Technology, vol. 70, no. 1, pp. 95-104, 1999.

[15] B. Mattuschka and G. Straube, "Biosorption of metals by a waste biomass," Journal of Chemical Technology and Biotechnology, vol. 58, no. 1, pp. 57-63, 1993.

[16] P. Sar, S. K. Kazy, R. K. Asthana, and S. P. Singh, "Metal adsorption and desorption by lyophilized Pseudomonas aeruginosa," 
International Biodeterioration and Biodegradation, vol. 44, no. 2-3, pp. 101-110, 1999.

[17] J. M. Tobin, D. G. Cooper, and R. J. Neufeld, "Uptake of metal ions by Rhizopus arrhizus biomass," Applied and Environmental Microbiology, vol. 47, no. 4, pp. 821-824, 1984.

[18] H. I. Al-Taweil, M. B. Osman, A. A. Hamid, and W. M. W. Yusoff, "Optimizing of Trichoderma viride cultivation in submerged state fermentation," American Journal of Applied Sciences, vol. 6, no. 7, pp. 1284-1288, 2009.

[19] P. Anand, J. Isar, S. Saran, and R. K. Saxena, "Bioaccumulation of copper by Trichoderma viride," Bioresource Technology, vol. 97, no. 8, pp. 1018-1025, 2006.

[20] Metcalf and Eddy, Wastewater Engineering Treatment and Reuse, Tata McGraw-Hill, New Delhi, India, 4th edition, 2003.

[21] S. Lagergren, "About the theory of so-called adsorption of soluble substances," Kungliga Svenska Vetenskapsakademiens Handlingar, vol. 24, no. 4, pp. 1-39, 1898.

[22] Y. S. Ho, G. McKay, D. A. J. Wase, and C. F. Forster, "Study of the sorption of divalent metal ions on to peat," Adsorption Science and Technology, vol. 18, no. 7, pp. 639-650, 2000.

[23] W. J. Weber Jr. and J. C. Morriss, "Kinetics of adsorption on carbon from solution," Journal of the Sanitary Engineering Division, vol. 89, no. 2, pp. 31-60, 1963.

[24] S. Wang, Y. Boyjoo, and A. Choueib, "A comparative study of dye removal using fly ash treated by different methods," Chemosphere, vol. 60, no. 10, pp. 1401-1407, 2005.

[25] C. K. Jain, "Adsorption of zinc onto bed sediments of the River Ganga: adsorption models and kinetics," Hydrological Sciences Journal, vol. 46, pp. 419-434, 2001.

[26] Z. R. Holan and B. Volesky, "Biosorption of lead and nickel by biomass of marine algae," Biotechnology and Bioengineering, vol. 43, no. 11, pp. 1001-1009, 1994.

[27] Y. Nuhoglu and E. Malkoc, "Thermodynamic and kinetic studies for environmentaly friendly $\mathrm{Ni}(\mathrm{II})$ biosorption using waste pomace of olive oil factory," Bioresource Technology, vol. 100, no. 8, pp. 2375-2380, 2009.

[28] M. Rao, A. V. Parwate, and A. G. Bhole, "Removal of $\mathrm{Cr}^{6+}$ and $\mathrm{Ni}^{2+}$ from aqueous solution using bagasse and fly ash," Waste Management, vol. 22, no. 7, pp. 821-830, 2002. 

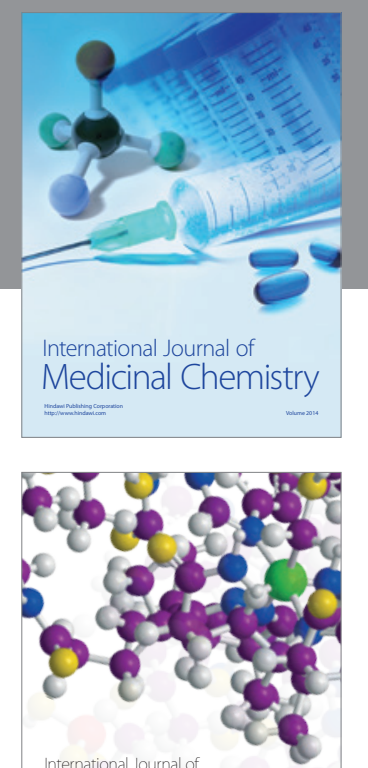

\section{Carbohydrate} Chemistry

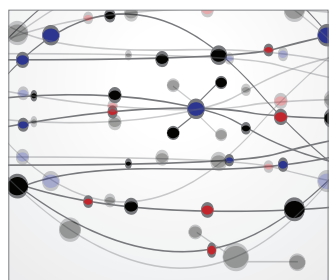

The Scientific World Journal
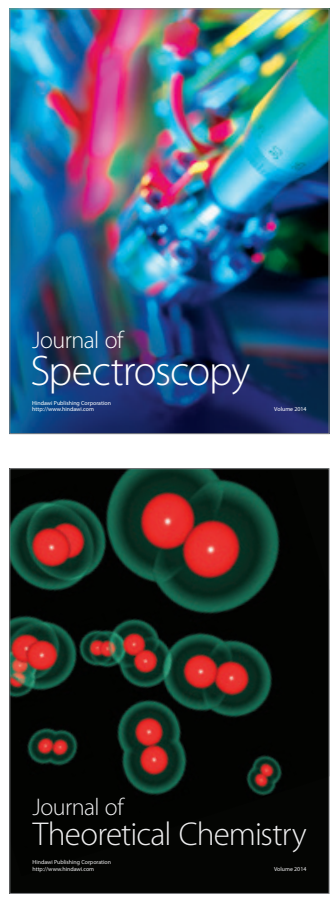
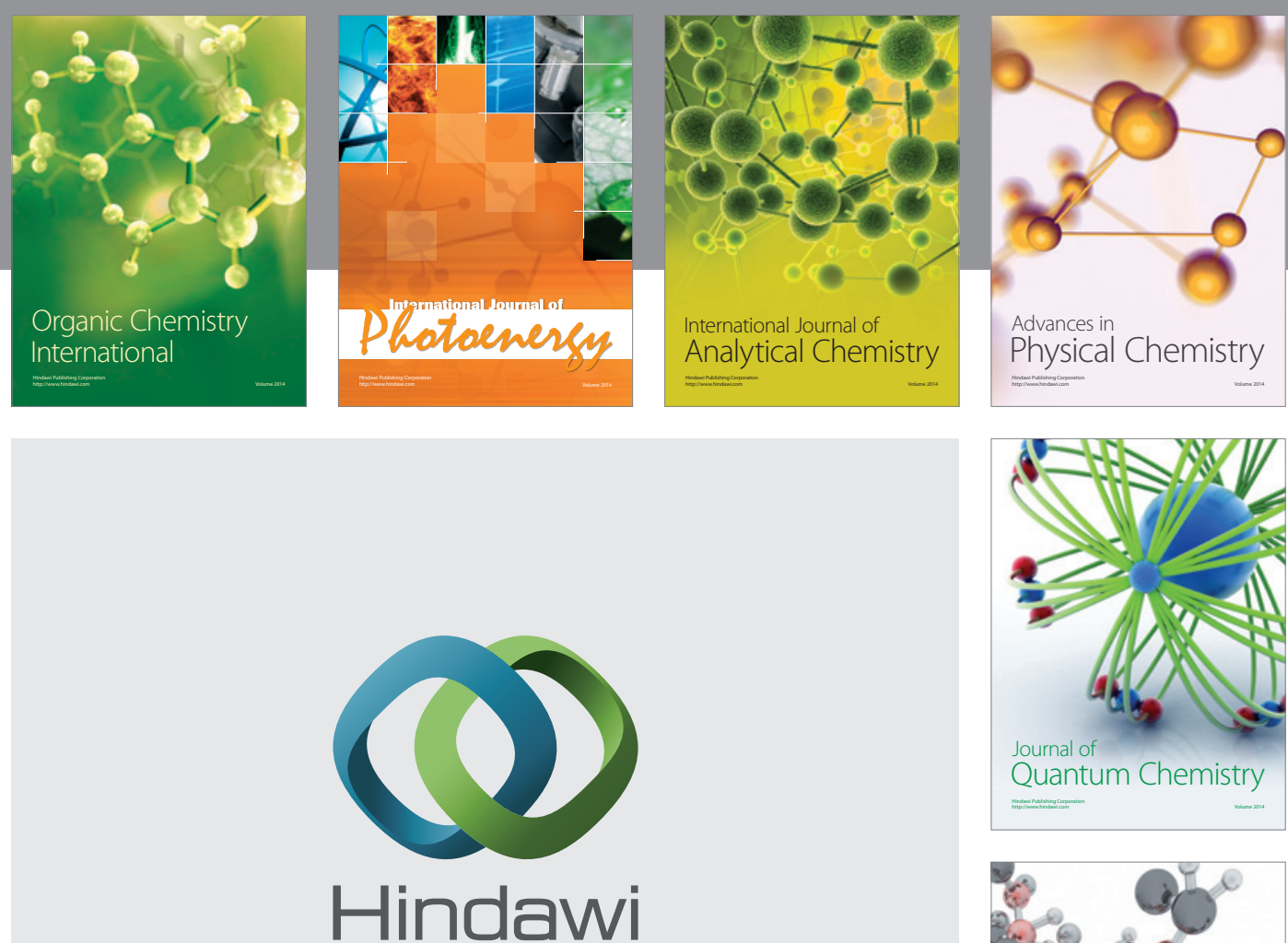

Submit your manuscripts at

http://www.hindawi.com

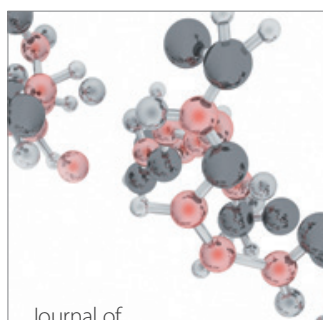

Analytical Methods

in Chemistry

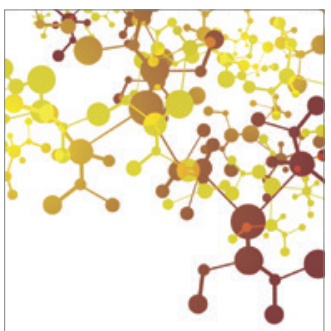

Journal of

Applied Chemistry

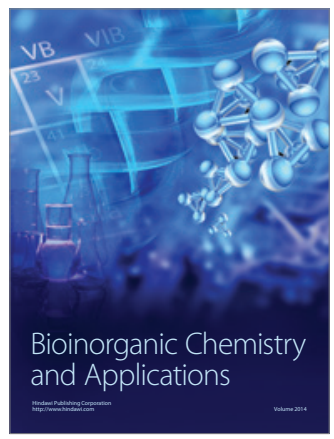

Inorganic Chemistry
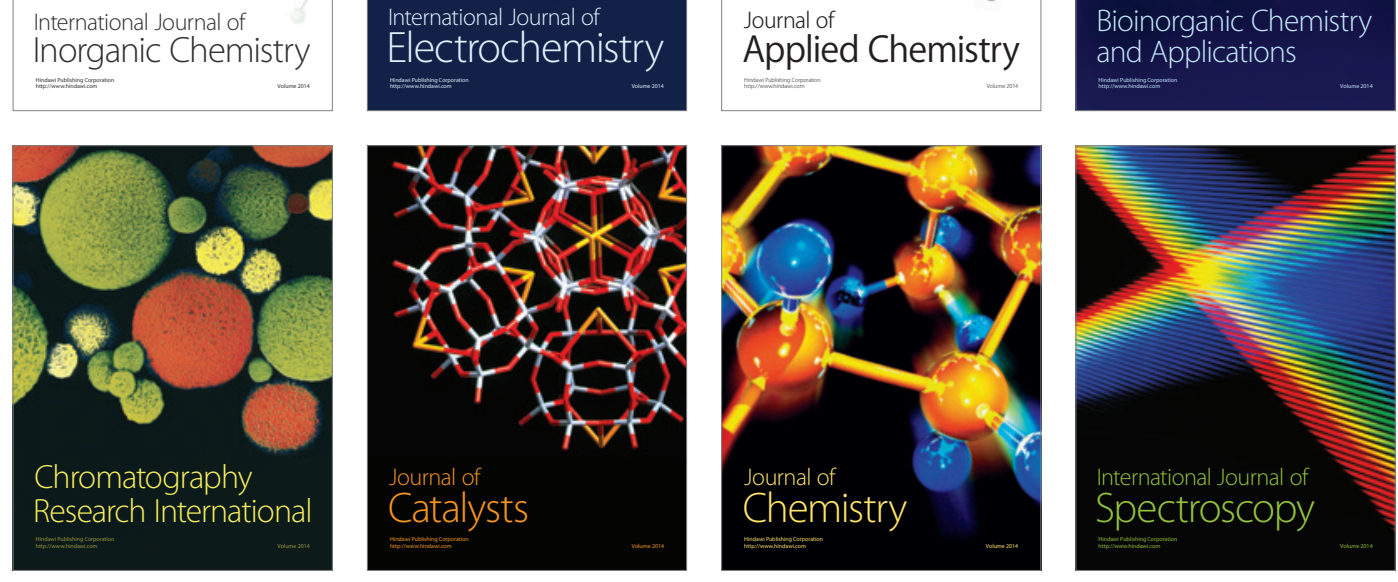